\title{
A New Concept of Circular Model of Management for Achieving Sustainable Success and Growth
}

\author{
Keerthan Raj ${ }^{1}$ \& P. S. Aithal ${ }^{2}$ \\ College of Management \& Commerce, Srinivas University, Mangalore- 575 001, India \\ 10rcidID:0000-0003-0190-4610, E-mail: 2keerthanraj@gmail.com \\ 2OrcidID:0000-0002-4691-8736, E-mail: psaithal@gmail.com
}

Area/Section: Management

Type of the Paper: Research Paper.

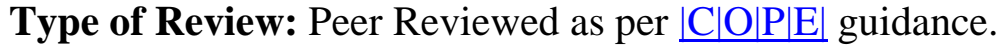

Indexed in: OpenAIRE.

DOI: http://doi.org/10.5281/zenodo.3634224.

Google Scholar Citation: IJMTS.

\section{How to Cite this Paper:}

Keerthan Raj, \& Aithal, P. S. (2020). A New Concept of Circular Model of Management for Achieving Sustainable Success and Growth. International Journal of Management, Technology, and Social Sciences (IJMTS), 5(1), 1-17. DOI: http://doi.org/10.5281/zenodo.3634224.

International Journal of Management, Technology, and Social Sciences (IJMTS) A Refereed International Journal of Srinivas University, India.

(c) With Authors.

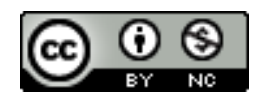

This work is licensed under a Creative Commons Attribution-Non-Commercial 4.0 International License subject to proper citation to the publication source of the work.

Disclaimer: The scholarly papers as reviewed and published by the Srinivas Publications (S.P.), India are the views and opinions of their respective authors and are not the views or opinions of the SP. The SP disclaims of any harm or loss caused due to the published content to any party. 


\title{
A New Concept of Circular Model of Management for Achieving Sustainable Success and Growth
}

\author{
Keerthan Raj \& P. S. Aithal \\ College of Management \& Commerce, Srinivas University, Mangalore- 575 001, India \\ E-mail:2keerthanraj@gmail.com
}

\begin{abstract}
According to the International Institute for Sustainable Development (IISD), sustainable development has been defined in many ways, and it states that: "Sustainable development is a development that meets the needs of the present without compromising the ability of future generations to meet their own needs." We have seen a lot of focus on sustainable development starting from the initiative of the United Nations which has made all nations focus on Sustainable Goals to be achieved by 2030, to large conglomerates and small business enterprises likewise focussing on sustainable business practices, which if well planned would yield success and growth. In light of the global challenges faced in relation to environmental, economic and social resources sustainable development leading to sustainable success and growth calls for a significant rethinking in the management of resources within the, and external to the organization. In this paper, we propound the furthering of a circular economy concept to management as 'circular model of management'. Borrowed from the concept of circular economy, a circular economy (as against a linear economy) is an economic system aimed at minimizing waste and making the most of resources. Moving towards a circular economy delivers benefits such as reducing pressure on resources, increases competitiveness, stimulates innovation and boosts growth. This study is developed through extensive work in subsistence communities (base of the pyramid customers) in emerging markets. A circular economy promotes social, environmental, economic and overall restorative and regenerative capabilities, similarly, a circular model of management will as envisaged promote regenerative and restorative capability in the organization which will ensure sustainable growth and success by means of ensuring the reduction of leakage of resources to the minimum and applicability to the maximum.
\end{abstract}

Keywords: Base of the pyramid, Circular economy, Circular model of management, Model, Sustainability.

\section{INTRODUCTION :}

A circular economy is a term that has assumed considerable importance over the last few years. Often referred to as 'circularity', is an economic system aimed at eliminating waste and the continual use of resources. While traditional linear systems follow the concept of take - make - use; dispose - pollute, circular systems employ make - use - reuse - remake - recycle concept to get the optimum utilization of resources. It aims at a closed - loop system minimizing the use of resource inputs and the creation of waste.
The circular economy thus would be more sustainable than the current linear economic system. The economic system based on the circular economy also looks at the opportunity to build circular business models. A circular business model articulates the logic of how an organization creates, offers, and delivers value to its range of stakeholders primarily aimed at minimizing ecological and social costs. Circular economy business models can be categorized in two groups: those which promote reuse and extend service life through repair, remanufacture, upgrades and retrofits; and those 
models that promote turning old goods into as new resources by recycling the materials [1]. People are central to the model. Ownership gives way to stewardship; consumers become users and creators. Circular businesses move ahead from a focus on pure profit maximization or cost cutting (traditional approach) to be achieved by building greater efficiency in supply chains, factories, and operations as the primary corporate objective. They focus on redesigning and restructuring the way products and services are created and sold to ensure not just current cost minimization or profit maximization but to focus on creating a sustainable ecosystem where products and services are not just sold to end customers but there is a bottom up approach to engaging them in business activities and building market competitiveness. The circular business model is a fundamental change and needs a new way of doing business and thinking. The same concept is applied to management and the dimensions of management to understand a better working model for managing organizations to contribute to growth, success, and scalability of the business.

\section{RELATED WORK:}

There has been work on the circular economy and conceptual understanding and linkages and benefits of the circular economy as mentioned below in Table 1 . However, we have identified that the linking of the circular economy concept to the concept of management is not available to date and this case study approach and critical analysis and synthesis have been developed after a thorough understanding of the existing body of knowledge on the circular economy.

Table 1 : Review of some of related publications in Circular economy concept

\begin{tabular}{|c|c|c|c|c|}
\hline Authors & Approach & Abstract & Title & $\begin{array}{c}\text { Year of } \\
\text { Publication }\end{array}$ \\
\hline $\begin{array}{l}\text { Uwe G. } \\
\text { Schulte }\end{array}$ & $\begin{array}{l}\text { Exploratory } \\
\text { study }\end{array}$ & $\begin{array}{l}\text { This explains the ideas of the } \\
\text { circular economy and addresses } \\
\text { new business models. } \\
\text { Incorporation of ecosystem } \\
\text { services into business models. } \\
\text { - The age of high commodity } \\
\text { prices is over and Energy (exergy) } \\
\text { being a major factor in future } \\
\text { business models is discussed. }\end{array}$ & $\begin{array}{l}\text { New business } \\
\text { models for a } \\
\text { radical change in } \\
\text { resource } \\
\text { efficiency }\end{array}$ & 2013 [2] \\
\hline $\begin{array}{l}\text { Antikainen, } \\
\text { M., et al. }\end{array}$ & $\begin{array}{l}\text { Business } \\
\text { Model creation }\end{array}$ & $\begin{array}{l}\text { There is comprehensive literature } \\
\text { on creativity in business models } \\
\text { (BMI). In addition, innovation in } \\
\text { the sustainable business model } \\
\text { (SBMI) blends the concepts of } \\
\text { sustainable business management } \\
\text { with creativity in the business } \\
\text { model. Survey on CE models and } \\
\text { responses to the same. }\end{array}$ & $\begin{array}{l}\text { Towards Circular } \\
\text { Economy } \\
\text { Business Models: } \\
\text { Consumer } \\
\text { Acceptance of } \\
\text { Novel Services }\end{array}$ & 2015 [3] \\
\hline $\begin{array}{l}\text { Sjors Witjes, } \\
\text { et al. }\end{array}$ & $\begin{array}{l}\text { Interpretative } \\
\text { Papers }\end{array}$ & $\begin{array}{l}\text { This paper studies sustainability } \\
\text { and is aimed at addressing } \\
\text { environmental as well as socio- } \\
\text { economic problems. The literature } \\
\text { on sustainability has primarily } \\
\text { focussed on environmental issues, } \\
\text { and of recent origin is the focus on } \\
\text { the concept of adoption of the } \\
\text { concept of Circular Economy as }\end{array}$ & $\begin{array}{l}\text { Towards a more } \\
\text { Circular } \\
\text { Economy: } \\
\text { Proposing a } \\
\text { framework } \\
\text { linking } \\
\text { sustainable public } \\
\text { procurement and } \\
\text { sustainable }\end{array}$ & 2016 [4] \\
\hline
\end{tabular}




\begin{tabular}{|c|c|c|c|c|}
\hline & & $\begin{array}{l}\text { an idea to tackle major } \\
\text { environmental and socio- } \\
\text { economic issues plaguing the } \\
\text { globe. This paper has inherently } \\
\text { proposed a shift from a so called } \\
\text { "traditional" process of public } \\
\text { procurement to a "service- } \\
\text { oriented" system that is focussed } \\
\text { on product selling models. The } \\
\text { paper proposes a systematic } \\
\text { structure to integrate technical and } \\
\text { non-technical product / service } \\
\text { combination requirements so that } \\
\text { they improve the efficiency of } \\
\text { resource use through recovery. }\end{array}$ & business models & \\
\hline $\begin{array}{l}\text { Antikainen, } \\
\text { M., et al. }\end{array}$ & $\begin{array}{l}\text { Case Study } \\
\text { approach }\end{array}$ & $\begin{array}{l}\text { In this paper, the authors create a } \\
\text { structure for sustainable circular } \\
\text { business model innovation by } \\
\text { incorporating critical perspectives: } \\
\text { identifying ecosystem-level } \\
\text { patterns and drivers; } \\
\text { understanding interest within a } \\
\text { business to partners and } \\
\text { stakeholders; and assessing } \\
\text { sustainability and circularity } \\
\text { impacts. }\end{array}$ & $\begin{array}{l}\text { A framework for } \\
\text { sustainable } \\
\text { circular business } \\
\text { model innovation }\end{array}$ & 2016 [5] \\
\hline $\begin{array}{l}\text { Andrea } \\
\text { Urbinati, et al. }\end{array}$ & $\begin{array}{l}\text { Literature } \\
\text { Review and } \\
\text { exploratory } \\
\text { case studies }\end{array}$ & $\begin{array}{l}\text { After thoroughly evaluating the } \\
\text { current contributions to Circular } \\
\text { Economy through the lens of } \\
\text { business model literature, the } \\
\text { authors suggest a taxonomy of } \\
\text { Circular Economy Business } \\
\text { Models that is primarily focussing } \\
\text { on the degree to which circularity } \\
\text { is adopted in two major } \\
\text { dimensions: (i) how the } \\
\text { application of the principle of } \\
\text { circularity can be used in } \\
\text { proposing value to customers; (ii) } \\
\text { creation of a value network, the } \\
\text { ways and means in which } \\
\text { suppliers interact and reorganize } \\
\text { their own internal activities. } \\
\text { Explorative case studies are used } \\
\text { to demonstrate different modes of } \\
\text { the adoption of the concept of } \\
\text { Circular Economy. }\end{array}$ & $\begin{array}{l}\text { Towards a new } \\
\text { taxonomy of } \\
\text { circular economy } \\
\text { business models }\end{array}$ & 2017 [6] \\
\hline $\begin{array}{l}\text { Alan Murray, } \\
\text { et al. }\end{array}$ & $\begin{array}{l}\text { Literature } \\
\text { Analysis }\end{array}$ & $\begin{array}{l}\text { Industry has long been looking for } \\
\text { guidance when adopting }\end{array}$ & $\begin{array}{l}\text { The Circular } \\
\text { Economy: An }\end{array}$ & 2017 [7] \\
\hline
\end{tabular}




\begin{tabular}{|c|c|c|c|c|}
\hline & & $\begin{array}{l}\text { sustainable } \\
\text { approaches. The Circular } \\
\text { Economy reflects the latest } \\
\text { attempt to conceptualize } \\
\text { sustainably the alignment between } \\
\text { economic activity and } \\
\text { environmental well-being. This } \\
\text { paper traces the Circular } \\
\text { Economy's conceptualizations and } \\
\text { origins, traces its meanings and } \\
\text { explores its economic and } \\
\text { ecological antecedents, and } \\
\text { discusses how the concept of } \\
\text { circular economy has been } \\
\text { operationalized in business and } \\
\text { policy. The authors have proposed } \\
\text { a definition of the Circular } \\
\text { Economy as "an economic model } \\
\text { wherein planning, resourcing, } \\
\text { procurement, production and } \\
\text { reprocessing are designed and } \\
\text { managed, as both process and } \\
\text { output, to maximize ecosystem } \\
\text { functioning and human well- } \\
\text { being". }\end{array}$ & $\begin{array}{l}\text { Interdisciplinary } \\
\text { Exploration of the } \\
\text { Concept and } \\
\text { Application in a } \\
\text { Global Context. }\end{array}$ & \\
\hline $\begin{array}{l}\frac{\text { Julian }}{\text { Kirchherr, et }} \\
\text { al. }\end{array}$ & $\begin{array}{l}\text { Theoretical } \\
\text { definition } \\
\text { analysis }\end{array}$ & $\begin{array}{l}\text { The paper analyses the concept of } \\
\text { a circular economy has gained } \\
\text { momentum among scholars and } \\
\text { practitioners alike. This paper } \\
\text { provides additional evidence to } \\
\text { critics who state that different } \\
\text { people mean different things when } \\
\text { discussing about the concept of } \\
\text { circular economy. The authors by } \\
\text { an analysis if } 114 \text { definitions of } \\
\text { the concept of circular economy } \\
\text { have tried to bring in some } \\
\text { transparency regarding the current } \\
\text { understandings of the concept of } \\
\text { circular economy. Herein, we find } \\
114 \text { descriptions of circular } \\
\text { economy being coded in } 17 \\
\text { dimensions. }\end{array}$ & $\begin{array}{l}\text { Conceptualizing } \\
\text { the circular } \\
\text { economy: An } \\
\text { analysis of } 114 \\
\text { definitions. }\end{array}$ & 2017 [8] \\
\hline S. Goyal, et al. & $\begin{array}{l}\text { Deductive } \\
\text { research }\end{array}$ & $\begin{array}{l}\text { This paper primarily looks at first } \\
\text { the linear economic model that is } \\
\text { driven by the philosophy of "take- } \\
\text { make-dispose" and brings to light } \\
\text { the fact that it is unable to manage } \\
\text { demand and supply balance in }\end{array}$ & $\begin{array}{l}\text { Circular economy } \\
\text { business models } \\
\text { in developing } \\
\text { economies: } \\
\text { Lessons from } \\
\text { India on reduce, }\end{array}$ & 2018 [9] \\
\hline
\end{tabular}




\begin{tabular}{|c|c|c|c|c|}
\hline & & $\begin{array}{l}\text { natural resource consumption. The } \\
\text { focus on the circular economy } \\
\text { model which focuses on bringing } \\
\text { about a careful coordination and } \\
\text { management of resource flows } \\
\text { right through the value chain by } \\
\text { the application of reverse } \\
\text { logistics, creativity in architecture, } \\
\text { integrated ecosystem and } \\
\text { innovation in business model } \\
\text { examined the manner in which the } \\
\text { circular economy model can be } \\
\text { applied. This article explores ways } \\
\text { and means in which the circular } \\
\text { model drives companies to } \\
\text { develop economies such as India } \\
\text { to design and implement business } \\
\text { models based on paradigms being } \\
\text { reduced, reused and recycled. }\end{array}$ & $\begin{array}{l}\text { recycle, and reuse } \\
\text { paradigms. }\end{array}$ & \\
\hline $\begin{array}{l}\text { Charbel Jose, } \\
\text { et al. }\end{array}$ & $\begin{array}{l}\text { Concept } \\
\text { Understanding } \\
\text { and integrative } \\
\text { framework } \\
\text { development }\end{array}$ & $\begin{array}{l}\text { This paper tries to integrate two } \\
\text { concepts - one of Circular } \\
\text { economy and one of Large-scale } \\
\text { data, the authors make the case for } \\
\text { circular economy (CE) and large- } \\
\text { scale data (LD), also known as big } \\
\text { data integration. The study } \\
\text { integrates CE-LD into an } \\
\text { integrative framework that also } \\
\text { provides insight into social and } \\
\text { technical realms for academics, } \\
\text { practitioners, managers, and } \\
\text { policy decision-makers. }\end{array}$ & $\begin{array}{l}\text { Unlocking the } \\
\text { circular economy } \\
\text { through new } \\
\text { business models } \\
\text { based on large- } \\
\text { scale data: An } \\
\text { integrative } \\
\text { framework and } \\
\text { research agenda. }\end{array}$ & 2019 [10] \\
\hline
\end{tabular}

\section{OBJECTIVE \& METHODOLOGY :}

In this paper of applying the concept of circular economy to circular management principles we have used the case study technique of companies operating in the base of the pyramid market has been analysed using the Critical Analysis Technique (CAT). This technique is based on Blooms Taxonomy. Bloom's Taxonomy is a set of hierarchical models used to classify educational learning, developed by educational psychologist Benjamin Bloom, which categorizes learning into three levels of human cognition- thinking, learning and understanding [11]. While originally propounded more than 60 years back, the cognitive domain which is the primary focus included six classification levels: knowledge, comprehension, application, analysis, synthesis and evaluation. The revised version, again has six categories aligned as Create, Evaluate, Analyse, Apply, Understand, Remember. Here, from the knowledge of the case studies, information is comprehended, applying to management situations in these companies operating in BOP market, an analysis of success or failure factors and reasons is made and this information synthesis process lead to the evaluation of the circular concept of management as proposed.

\section{CRITICAL ANAL YSIS TECHNIQUE OF CASE STUDIES :}

Benjamin Bloom, almost 70 years ago had put 
forward the concept of Blooms Taxonomy on how knowledge can be assimilated to higher order thinking [2]. Applying this concept, we understand that for any higher order thinking critical for development of new knowledge, existing information and knowledge on the basis of and evaluation and synthesis of case studies on companies operating in BOP market and on BOP sellers an analysis has been developed, BOP market is by and large a very huge opportunity for marketers, it is the most difficult market to enter and serve as it is characterized by a vast set of homogenous but diversified set of potential customers [12]. If organizations are able to harness the potential of this market it will give a much larger opportunity to tap while looking for growth, scalability of operations and reaching out to untapped areas [13]. Hence, this synthesis and analysis is focussed on merging some of the successful BOP strategies and analysis has been applied to the concept of management to evolve a new concept relevant to the study of successful sustainable growth and management.

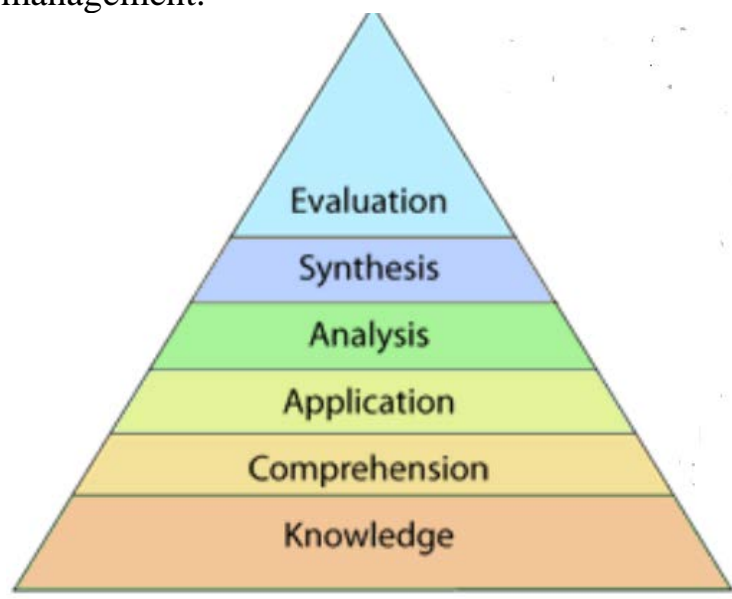

Fig. 1: Blooms Taxonomy (Source: Knowledge Management)

Case Study 1 and Observations :

Case study of the industry of indigenous businesses (base of the pyramid market) :

Challenges and constraints of sellers in subsistence markets have been identified as follows [13-15]. The following are the challenges faced by sellers in BOP/subsistence market

(1) Lack of access to credit, working capital and investment credit-

Subsistence market sellers are consistently faced this constraint of low or non-existent credit facilities. Most of the times these sellers are selling a multitude of sometimes, diversified set of products that they would have purchased from larger markets; this being the reason they face a lack of cash credit system or inventory credit facilities [14,15]. In the absence of a social security system, lack of access to and poor availability of credit facilities these low-income individuals with limited means at most times pool in their personal resources to gather money to start the business and run it. There is dearth of working capital and investment capital. However, in spite of this, these sellers are faced with the issue of having to sell their products and services at credit to their customers, especially when their customers belong to the BOP segment.

(2) Weak networks-

Weak networks refer to the value chains that could be made available to sellers by middlemen, wholesalers or large retailers from whom these sellers will be purchasing their products [13 -16]. For instance, if a seller of locally or homemade biscuits, spice powders etc would have been able to gather value chains, he could look at stacking up an inventory of other product ranges that the large retailer would be having and this would give a depth of the customers shopping basket and a bigger chunk of profits for the seller, while for the customer he can purchase all his household needs at one seller. Due to the lack of advantages available in being able to scale up the business, add products along the suite the value chain advantage is not available due to lack of networks to make the business more adaptable to customer needs and requirements. This value chain and ecosystem advantage is not available for the sellers in subsistence markets. 


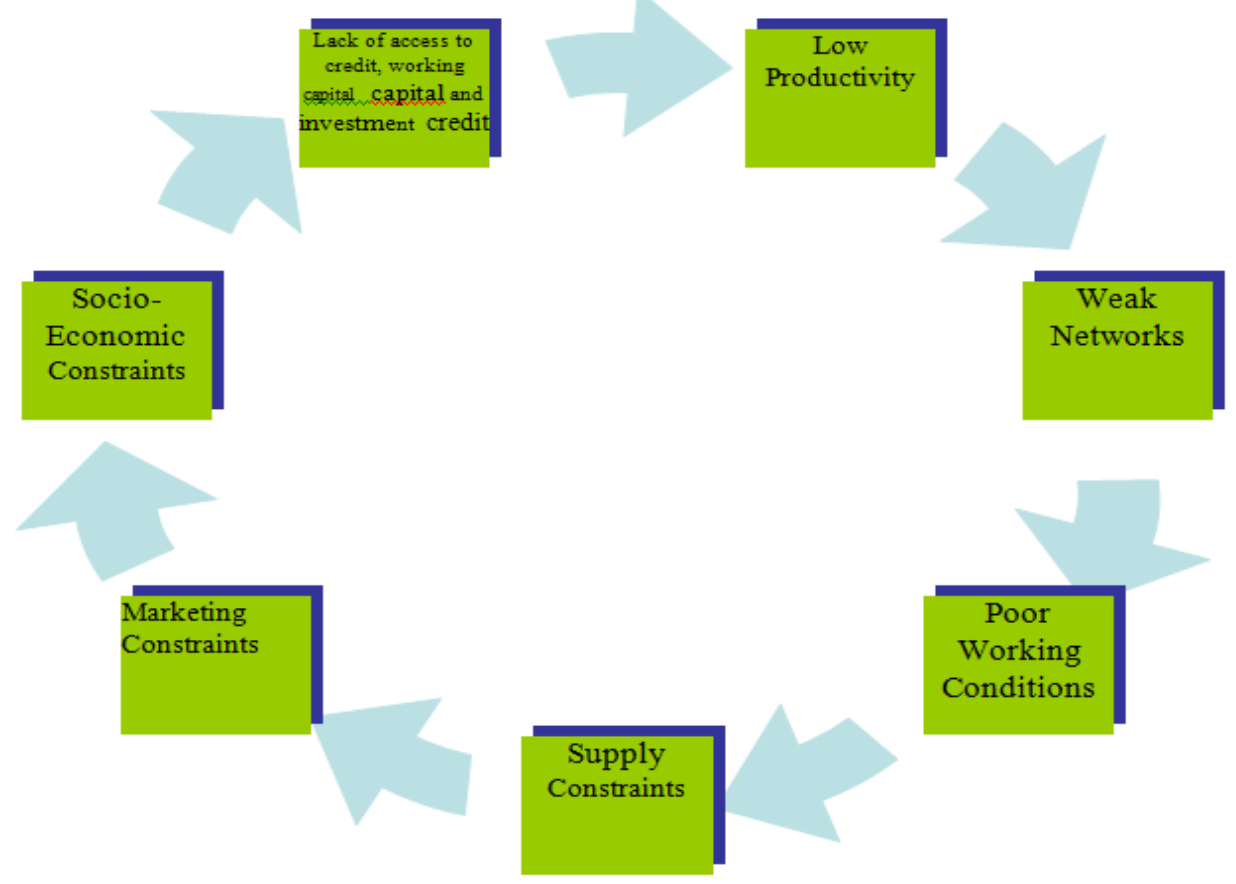

Fig. 2: Challenges of sellers in subsistence market

\section{(3) Low productivity-}

Productivity is the relationship between inputs and output, while for a large retailer he would be able to get maximum productivity from his equation of inputs to output, for a street vendor, his inputs would by far outweigh his final output and he is most times working on thin margins and productivity. Sellers in subsistence markets, (our discussion here is limited to BOP category sellers and not larger companies who might be selling to BOP market) would need to scout for good quality products, get it at the right prices, there will not be one regular supplier, no credit facilities, most of the sellers purchases would be against cash so if he is giving credit to this customers, at most times this would again erase or diminish his margins and profits if we account for the opportunity costs associated with doing business with his customers on credit.

\section{(4) Poor working conditions-}

Poor working conditions are endemic to BOP sellers in BOP market, nonexistence of adequate and proper storage facilities, make- shift selling spaces, power cuts, water shortages, lack of basic sanitation facilities, most subsistence market consumers and sellers grapple with poor working and living conditions in their lives. This inadvertently most of the times, also affects the quality of their lives. From the point of view of product development to after sales scenario these poor working conditions highly affect products that are purchased, the places from where they are purchased and when and how and from whom they are purchased.

\section{(5) Supply constraints-}

Lack of buyers' credit facilities from suppliers, wholesalers or lending institutions and the absence of value chains, "ecosystems" are all interlinked 3]. By and large sellers in subsistence markets coexist with other sellers by selling products and services which are critical and price variations are acceptable only within certain limits. This being the case sellers faces a lot of non-credit related barriers such as supply to try and procure their goods at the lowest cost possible. Most of the times, BOP sellers in this market have no one regular supplier and wholesaler that they can tie up with because of issues related to volumes, credit terms, inventory purchase abilities and a host of other economic constraints making supply a major issue. The BOP seller buys his products and services from a diverse range of wholesalers, large retailers or manufacturer representatives whichever suits his 
product profile and capital flows best.

\section{(6) Marketing constraints-}

Subsistence market/BOP consumers have a unique characteristic of relying very heavily on word of mouth communication and one to one social interactions. For a seller in this market this holds a lot of promise because he can rely heavily these word of mouth publicity and the social interaction channels to carry his message forward. The seller here cannot afford to spend time and money on any other type of marketing efforts. The reason being his products and services sell mostly by w-o-m and one to one interaction and a close-knit bond with the few customers who would in turn attract other buyers. Even then, a small discount or a "free" promotion offered by any other fellow seller will severely affect other sellers if they cannot match up with any such similar offers.

\section{(7) Socio-economic constraints-}

Low education and literacy levels, lack of basic amenities', poor or no access to logistic and distribution networks, poor sanitation, lack of resources to mobilise adequate transportation and storage facilities are only some of the socioeconomic constraints of the seller in subsistence markets.

Buyers and most of the sellers in subsistence markets have low education, low standards of living and most of their incomes are spent on purchasing sustenance products and services, needless to say, some smart marketers and large business corporations like Reliance Communications in India during 2003, made available mobile phone connections with handsets at 500 INR thus sphere heading a movement of low cost mobile handsets being made available to the BOP customers as well [3]. Within the realm of socio-economic constraints, sellers in subsistence markets have to scout for products that they can purchase at lower costs so they could sell it to their customers at a considerable mark-up. There is a constant interaction with other sellers and buyers in these markets, this helps them to leverage their and others knowledge on products and services.

(8) Indigenous practices adopted by subsistence marketplace sellers -
Most of the BOP market is characterized by a very close-knit connection of interdependence between sellers and buyers in these resource poor settings. And since most come from a similar socio economic background and share similar adversities, many buyers would have experience as a seller at some point or other. Their interactions thus would be influenced by a deep empathy for each other. Thus, firms and researchers efforts to understand the successful practices have twin advantages. One is to develop a bottom up approach to understanding how to serve and succeed in these markets. Two, is to pave the way to enable the adoption of these successful and indigenous practices in other niche markets if possible.

Sellers or vendors in the $\mathrm{BOP} /$ subsistence marketplace have been in this business of buying and reselling or in some cases of manufacturing themselves at a very small scale and selling since a very long time. Certain vendors in this market have become monopolies for their unique offerings and other sellers have not been able to break this monopoly created by the seller due to some advantages that may be available to them. These few vendors have become brands by themselves today or they have created their brand identities. In any market around us when we look closely, we will find them, it could be a local fried snacks producer or a papad (Indian sun dried preparation as an accompaniment to rice meal), a pickle producer and seller in our neighbourhood. It could be the street corner barber who has today managed to set up his own small self styled saloon which is even now thronged with customers. There are certain unique indigenous practices that have made them stand out. These could be listed out as follows -

1. Network- One of the most significant pinup points of a BOP seller in a subsistence market is the very strong social networks they have built around them. Subsistence market normally has a unique characteristic of being a close-knit market between buyers and sellers. Every small transaction involves frequent and detailed one to one interaction and exchange of information of general nature. The interactions are such deeply set that product and service purchase seems only 
a secondary non important criterion. These strong social networks make it impossible for any other seller to gain entry into any particular seller's customer base. This market is characterised as having high one to one interaction between small neighbourhood sellers and local consumers showing the significance of combining economic and social relationships among players in the marketplace. HLL, in India has tried and succeeded in this winning practice of building an economic and socially networked selling space in rural and semi urban centres through its shakti programs which partnered with local womenfolk to partner and sell its products and services as micro franchisers. In fact, micro franchising takes this vast socio economic networking to another level to strategize it into a win -win situation for both the players.

2. Providing Value Propositions- Certain product suites in subsistence markets run exclusively due to their specific need in that BOP category. For instance, a local key making, lock repairing services, shoe making to suit specific target customer needs, buying set of products and disassembling and selling parts of it which might be the requirement in these markets. There are numerous such examples of products and services in markets around us, providers of which have become brands in themselves. Their services might be used not just by subsistence buyers but customers from other markets who have higher standards of living would be attracted to or use these services. The value proposition that it would provide to these buyers is what makes the seller successful. Be it in any marketplace if the customers do not perceive value, the product or a service sale becomes very negligible. Especially, in subsistence markets buyers have very little manoeuvrability in terms of price variations or the product fulfilling their need; hence they are very keen on cashing in the value box within the given available constraints.

The value chain in a subsistence marketplace-

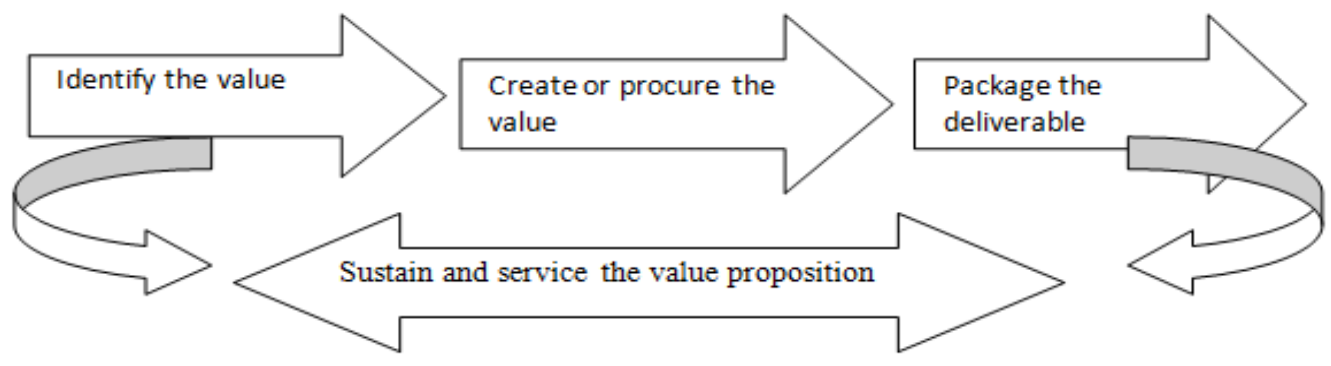

Fig. 3: The value chain in a subsistence marketplace

For sellers in subsistence market it is very essential that they find a value or critical want that needs to be satisfied in their products and services. The buyers here have limited financial resources and limited literacy, within these constraints they have to scout for products and services that will fulfil their need and provide value for the money that they spend for the product or service. Hence, the seller has to identify the critical value that he can provide within a price parameter, create or procure that value product/service at the least cost available, package the deliverable and ensure that this value chain is an ongoing continuous exercise in all products and services that he is selling.
Subsistence markets sellers increase consumer acceptance by giving low cost diversified critical products and services which could not be got elsewhere.

3. Effective Word of Mouth- A continuum of the networked strength that sellers in this market is that they strategize on the one to one interaction to act as promotional programs for them. In the absence of resources to spend on promotions buyers themselves act as carriers of word of mouth publicity and promotion for the sellers. This is due to the fact that the buyer seller relationship here transcends beyond just the economic exchange. The seller treats the buyer more or less as a family member and vice 
versa, there is a lot of social interaction and psychological contract that binds buyers and sellers. Even though the seller lacks purchase credit himself, he is always willing to give credit to his buyers which forge their bond forward. Lot of sellers function on daily, weekly and monthly payment schemes for their buyers much before large corporations started the equated Monthly Instalment schemes. For the part of buyers this ties them to the seller for long periods. The seller on his part is willing to take up the risk of the dues going bad. The Grameena bank concept, that was started if Bangladesh by Mohammed Yunus and many other such cons pets that have been enforced are affective due to the high level of word of mouth promotion [14, 15]. In South India, the district of Dakshina Kannada has a well-established microfinance schemes and well entrenched in the local populations.In this scheme, financial fabric, agricultural product schemes that have been very successfully adapted very willingly due to effective word of mouth publicity. Human psychology is such that we are willing to take up a suggestion by some kith and kin more easily than by a forum of media publicity.

4. Adaptivity- The BOP market is not typically a large homogenous market, but is seen in every urban, semi urban or rural centre might be characterized by its own set of local customs, needs and circumstances. One distinct product or service offering cannot be tailored to the entire nations market. Sellers in these markets are very successful at tailoring products and services to their immediate buyer community. It is very critical to identify with the needs and requirements of the customers rather than spend crores of rupees in advertising unwanted and unnecessary products services that is not tuned in to local cultures. Also, since there is socio economic interaction to a very high level it is easy for sellers to understand the nerve of the buyer community. It helps the sellers to pick up suitable businesses and product suites.

5. Critical Need Identification- As a continuation to providing value, seller has to identify critical needs of the buyers. Since most customers in subsistence markets have low incomes and are able to purchase only essential goods and services, a seller to be successful has to package his product to fill the want of a critical need. As Reliance Telecom did in India, they recreated a mobile handset which could be purchased at a minimal price and payment in instalments also ensuring that the critical want of a subsistence buyer for mobile connectivity could be converted into a need overnight. Buyers in BOP market realised that this service was affordable to them now. So also, with water purifier business in India, many sellers in BoP markets have used this critical 'want' identification and sold products or services by making them a 'need' for the buyers and providing it on credit terms or in easy purchase methods.

6. Localized Productions or sourcing- In a BOP market, there are several sellers who try and procure goods and services locally or try to procure it from the local manufacturers/growers. The buyers in some cases might be providing the raw materials for the finished goods. This can also hold good for sellers in the industry of handicrafts. Most of the artisans or handicrafts are manufactured in BOP markets the resources are procured locally and sellers go through strenuous efforts to create beautiful crafts, handloom products, potteries etc. Even in the case of the street food industry the raw materials for manufacturing the finished goods, be it pickles, papads, street fast foods are all procured locally at the source of sale. The buyers in these cases could be from the BOP markets and from the across other niche categories, even high-end customers, especially in the case of handicrafts etc. Also, in India there is the transitional informal market called, sandy bazaars, "santhes" where buyers and seller meet once a week to exchange goods and service for a price. Bargaining is a characteristic of subsistence marketplaces in India [13]. In certain cases, the buyers also may be sellers and vice versa. It has its own set of regular customers predominantly who transact heavily on the one to one networking created over the years. There are a lot of free moving customers also who need not necessarily be from the subsistence class of customers.

7. Proximity and flexible terms of purchase- 
The most interesting aspect of BOP/subsistence marketplaces is the sellers' ability to give very flexible terms of purchase or resale for its buyers. The sellers are at very close proximity to the buyers and the seller is willing to offer credit- short term and long term, buy back products, resell buyers goods if required and a host of other specialized services which has made them successful at their trade. For customers in the BOP subsistence customers who come from low income groups and have limited means to socialise, these informal arrangements and relationships create a deeper bonding with the customer. This is by far not possible for large business corporations and retailers, but many are trying to tie up with local sellers and create this bon homie.

Case Study 2: About HUL:

From the case study of Hindustan Unilever Limited that was published in an earlier paper about the base of the pyramid market and the reasons for success and failure of these ventures [15]. HUL was able to make many inroads into India's BOP and rural market mainly through their strategies to minimize serving sizes and to sell small quantities. HUL learned very early that growth would be at the bottom of the pyramid in India, particularly for the class of products it dealt with, particularly soaps, detergents, oils that are necessities. To find growth they had to find ways to penetrate into the rural and semi urban segments through the right approach. This they did through local stockists, in the BoP segments; by partnering with them in growth and sharing the revenues with the locals. This step had a profound impact on the reach of HUL. HUL was able to get into the mass market through a subtle entry by appointing persons of local communities and having local small retailers to stock and sell its products and services. During the 1970's, Bangladesh had seen a huge success in making retail credit accessible to the poorest of the poor under the guidance of Muhammed Yunus, Nobel Laureate professor at the University of Chittagong. HUL, learnt from this model and implemented it in its own growth and expansion drive to have a first mover advantage in the Fast Moving Consumer Goods Market (FMCG). In India and reach the smallest of small village in India, they initiated work with local Self-Help Group's (SHG's). HUL devised a growth and penetration strategy by asking local SHGs to operate as direct to home teams of sales women. This growth plan called Project Shakti, was a commission-based income generation scheme targeted at women. This program enabled HUL to advent onto the company's vision of building sustainable living and community involvement exercises in India in a large way.

Consumer data on subsistence markets is extremely limited, their tastes and preferences are diverse and hard to determine through traditional consumer surveys, using technology to its best advantage, HUL built a GPS and density mapping technology to design its rural supply chains and sales networks [15], [16].

The ambitious project Shakti of HUL, empowered local women by giving them income as well as through community development it gave access to better quality of living and hygiene awareness. Most importantly, among others, this paved the way for HUL to create a lasting and difficult to copy business model.

Strategy and Impact on business: Here we look at some of the significant strategies that impacted the business growth of HUL positively and its impact on its businesses (Table 2).

Table 2 : Strategy and Impact on business

\begin{tabular}{|c|c|}
\hline Strategy of HUL & Impact \\
\hline $\begin{array}{l}\text { Customisation } \\
-\quad \text { Reduced serving sizes in product } \\
\text { portfolio } \\
\text { - Different variations of the core product } \\
\text { for different segments }\end{array}$ & $\begin{array}{l}\text { HUL was one of the earliest companies to customise } \\
\text { products to reach out to mass markets, by breaking } \\
\text { into smaller serving sizes ensuring affordability, } \\
\text { customising it to suit the targets cost and value } \\
\text { requirements }\end{array}$ \\
\hline
\end{tabular}




\begin{tabular}{|l|l|}
\hline Rural Penetration & $\begin{array}{l}\text { Rural India is estimated to account for more than } \\
50 \% \text { of the total FMCG market in India; HUL has a } \\
\text { first mover advantage in this. }\end{array}$ \\
\hline Backward Integration & $\begin{array}{l}\text { HUL introduced concepts of backward and forward } \\
\text { integration across the value chain with local farmers } \\
\text { to source tomatoes for ketchup and such other } \\
\text { initiatives' }\end{array}$ \\
\hline Outsourced Manufacturing & $\begin{array}{l}\text { To leverage on scalability of business HUL went on } \\
\text { to outsource manufacturing to cater to market } \\
\text { requirements to meet demand requirements and } \\
\text { sustainable growth to the economy as well. }\end{array}$ \\
\hline Scalability of distribution networks & $\begin{array}{l}\text { Following on the model of the microfinance } \\
\text { initiatives' ensured penetration to the lower levels of } \\
\text { the socio economic fabric and also created financial } \\
\text { freedom and informed choice purchases. }\end{array}$ \\
\hline Community Understanding & $\begin{array}{l}\text { HUL has a practice of ensuring that managers at all } \\
\text { locations spend minimum } 6 \text { weeks in the BOP market } \\
\text { to actively gather consumer insights and preferences' } \\
\text { which helped generate more than 1 billion \$ in } \\
\text { revenues from this market in India. }\end{array}$ \\
\hline
\end{tabular}

On the basis of this and several other base of the pyramid operational strategies, we have developed the concept of the circular model of management.

\section{CIRCULAR \\ MANAGEMENT} CONCEPT:

Circular Management is a function of incorporating stability and sustainability in resources, policies, processes and practices in the organization

$$
\mathrm{CM}=\mathrm{f}\left(\mathrm{r}_{\mathrm{s}}, \mathrm{p}_{\mathrm{s}}, \mathrm{p}_{\mathrm{s}}, \mathrm{p}_{\mathrm{s}}\right)
$$

Where ' $r_{s}$ ' represents scares resources,

$\mathrm{p}_{\mathrm{s}}$ represents stable and sustainable policies

$\mathrm{p}_{\mathrm{s}}$ represents stable and sustainable processes

$\mathrm{p}_{\mathrm{s}}$ represents stable and sustainable practices

Circular Management calls for complete redefining of the organization's core policies, practices and processes to redeploy resources in a way that there is recreation, reuse, readjustment so as to have the least loss of usability. The end process has to be managed in such a way that it leads to continuity and is not wasteful destruction of any kind of resource.

Circular form also encompasses ensuring that the creation sustenance and destroying of resources which is also translated into creation, sustenance and dismantling or deconstruction to recreate-

Mgt = f ( L, Lr, K, Entrepreneurship ) - (1) Management, as we have traditionally applied is the function of managing the key resources of land, labour, capital and entrepreneurship.

Mgt $=\mathrm{f}(\mathrm{C}, \mathrm{S}, \mathrm{D})$

Simultaneously, management is also to be considered always with either the creation, sustenance or gradual dissemination of resources to create meaningful use to the organization, society and economy.

Considering, both are functions of management, and the resultant output for management is the same, we can conclude that modern management in the $21^{\text {st }}$ century has to be applicable to the ensure sustainable business practices in the creation, usage and deployment of the four key resources of an organization, hence -

$\mathrm{F}(\mathrm{L}, \mathrm{Lr}, \mathrm{K}, \mathrm{Ep})=\mathrm{F}(\mathrm{C}, \mathrm{S}, \mathrm{D})$

Hence, the concept of management in today's day and age is not limited to the basic five functions of planning, organizing, staffing, directing and controlling but encompasses in totality the functions needed to create, sustain and to also preserve and take care of the cyclical 
nature of destruction and regeneration. While we apply the concept of circular management, we can draw inspiration from all of spirituality that also speaks of the essence of the holy circle of creator, sustainor and destroyer. Man, in his quest to create livelihood, thriving economic and social wellbeing is constantly working very hard to create new enterprises and run them successfully with the universal wellbeing in mind. This being the fierce behind creation most organizations do not look at the last aspect of destruction or amicable dismantling of processes/ products/ companies so as to have least disruption and hardship to all involved. If this concept is also incorporated as a critical function of management it will serve the organizations better.

Let us look at the application of this circular philosophy in the important management activities traditionally looked at (Table 3).

Table 3: Application of circular philosophy in some of the important management activities

\begin{tabular}{|c|c|c|c|}
\hline Activity & Creation & Sustenance & Disengagement \\
\hline Finance & $\begin{array}{l}\text { Accumulating resources } \\
\text { together }\end{array}$ & $\begin{array}{l}\text { Successful utilization } \\
\text { of available resources }\end{array}$ & $\begin{array}{l}\text { Continuity plan for acute fund } \\
\text { crunch situations and } \\
\text { dismantling of non-profitable } \\
\text { businesses }\end{array}$ \\
\hline Human Relations & $\begin{array}{l}\text { Building of a human } \\
\text { force in organizations } \\
\text { (staffing, training) }\end{array}$ & $\begin{array}{l}\text { Nurturing of this team } \\
\text { to a competitive } \\
\text { advantage through } \\
\text { training and } \\
\text { development. }\end{array}$ & $\begin{array}{l}\text { Organizations should need to } \\
\text { develop a competent plan to } \\
\text { phase off employees and } \\
\text { rebuild skills, talent, and } \\
\text { capabilities }\end{array}$ \\
\hline Production & $\begin{array}{l}\text { Transforming crude raw } \\
\text { materials into value } \\
\text { added products and } \\
\text { services. }\end{array}$ & $\begin{array}{l}\text { Focussed on least } \\
\text { disruption to existing } \\
\text { conditions and } \\
\text { maximum opportunity } \\
\text { for co-option of } \\
\text { diverse possibilities }\end{array}$ & $\begin{array}{l}\text { Breakdown of product/service } \\
\text { with least harm or degradation } \\
\text { to the ecological balance. }\end{array}$ \\
\hline Marketing & $\begin{array}{l}\text { Creation of } \\
\text { communication to serve } \\
\text { the purposes of } \\
\text { awareness, interest, } \\
\text { desire and action of } \\
\text { customers to the } \\
\text { organizations offerings } \\
\text { in a cost effective value } \\
\text { based manner. }\end{array}$ & $\begin{array}{l}\text { Ensuring that the so } \\
\text { created peripherals of } \\
\text { marketing are } \\
\text { sustainable in terms of } \\
\text { value to the customer } \\
\text { segments and } \\
\text { product/service groups } \\
\text { as they evolve } \\
\text { overtime. }\end{array}$ & $\begin{array}{l}\text { In certain situations, evolution } \\
\text { may not be possible when it is } \\
\text { essential to phase out certain } \\
\text { activities and set in newer } \\
\text { more relevant practices. }\end{array}$ \\
\hline Technology & $\begin{array}{l}\text { Being the life blood of } \\
\text { business today, oriented } \\
\text { towards change } \\
\text { embedded processes. }\end{array}$ & $\begin{array}{l}\text { Technological enablers } \\
\text { that help in sustaining } \\
\text { critical business } \\
\text { practices leveraged on } \\
\text { technology. }\end{array}$ & $\begin{array}{l}\text { End use technology and the } \\
\text { manner in which it needs to be } \\
\text { dismantled has to be least } \\
\text { disruptive and disastrous. }\end{array}$ \\
\hline
\end{tabular}

Based, on the discussion above on the various application that needs to be engaged in key management areas we have put forward a list of strategic dimensions for application of the same circular management concept and the concerned applicable field for the same. For instance, in the task of resource mobilisation and utilization, which could involve material, financial, human, natural or any other kind of resource, to make it relevant for circular management it has to follow a principle of shared value chain amongst the various management areas and an example of the applicable field could be product design and 
so on from the production perspective. Similarly in the human resource dimension, circular management which is a concept grounded on least leakage of resources, cost, value, human capital needs to be looked at in developing

Table 4: Strategic dimensions of Circular thinking

\begin{tabular}{|l|l|l|}
\hline Strategic Dimensions & Applicable fieldsfor application of Circular Thinking \\
\hline $\begin{array}{l}\text { Resource Mobilization } \\
\text { \& Utilization }\end{array}$ & Shared Value chain & $\begin{array}{l}\text { Product design, usage, refurbishing, } \\
\text { recycling capabilities and return }\end{array}$ \\
\hline Human Capital & Collaborative work practices & $\begin{array}{l}\text { Focus on diversified workforce with } \\
\text { minimum disruption in work schedules }\end{array}$ \\
\hline $\begin{array}{l}\text { Sustainable Business } \\
\text { Practices }\end{array}$ & $\begin{array}{l}\text { Product Life extensions } \\
\text { Minimize negative impacts }\end{array}$ & $\begin{array}{l}\text { Focus on Internal \& External quality } \\
\text { enhancement }\end{array}$ \\
\hline $\begin{array}{l}\text { Innovations \& Natural } \\
\text { Management }\end{array}$ & $\begin{array}{l}\text { Instill practices to enable } \\
\text { fostering of cradle to } \\
\text { cradleconcept in all } \\
\text { paradigms of management }\end{array}$ & $\begin{array}{l}\text { Minimal invasion of natural systems for } \\
\text { maximum efficiency }\end{array}$ \\
\hline Management Practices & $\begin{array}{l}\text { Continued ownership and } \\
\text { seamless transitions }\end{array}$ & $\begin{array}{l}\text { Closed loop leading to increased } \\
\text { effectiveness }\end{array}$ \\
\hline
\end{tabular}

\section{ADVANTAGES OF ADOPTING THE CIRCULAR MODEL :}

- Optimum usage of resources - Circular concept is primarily inspired by the theme of circularity, which has no leakages. Hence, when we discuss circular model it has no scope for wastage of resources and looks at ways to replenish, reuse, reduce and recycle on all parameters.

- Significant movement towards building sustainability - Circular model as it amplifies least wastage of resources, will drive organizations towards accomplishing a critical need and goal of the $21^{\text {st }}$ century which is sustainability. Sustainability as a concept has two connotations - one from the perspective of environmental conservation and maintains ecological balance, two from the perspective of sustaining the business for a long time. collaborative practices wherein diversified workforce who could multitask overtime in a way to simplify tasks and maximize revenue and objective attainment through special skill is aimed. effectiveness 
gainfully employable anymore. But the circular concept looks at quasi hiring mechanisms, co-operative partnerships and so on which would make it an unending cycle of relationships and success for the resources and the organization.

- Regenerative approach on various facets of production and ownership and securing the benefit by focusing on the service business model.

\section{CONCLUSION :}

The circular economy has been a researched topic only for the last 4-5 years and as we can see from the various literature reviews it has evolved through its application in certain fields, nonetheless, this concept of the movement from a linear economy to a circular economy is a result-oriented approach. It is currently one of the most result bearing approaches to development and sustainable growth. It involves the integration of concepts to create a holistic approach to management in its current dimension and thought. The paper brings to fore the importance of extending, understanding and applying this concept to the various dimensions and facets of the circular model of management. As discussed above in detail, this application would ensure the reduction of leakage of resources to the minimum and applicability to the maximum.

\section{REFERENCES:}

[1] Stahel, W. R. (2016). The circular economy. Nature, 531(7595), 435-438.

[2] Schulte, U. G. (2013). New business models for a radical change in resource efficiency. Environmental Innovation and Societal Transitions, 9, 43-47.

[3] Antikainen, M., Lammi, M., Paloheimo, H., Rüppel, T., \& Valkokari, K. (2015, December). Towards circular economy business models: Consumer acceptance of novel services. In ISPIM Innovation Symposium (p. 1). The International Society for Professional Innovation Management (ISPIM).
[4] Witjes, S., \& Lozano, R. (2016). Towards a more Circular Economy: Proposing a framework linking sustainable public procurement and sustainable business models. Resources, Conservation and Recycling, 112, 37-44.

[5] Antikainen, M., \& Valkokari, K. (2016). Framework for Sustainable Circular Business Model Innovation. Technology Innovation Management Review, 6(7), 5-12.

[6] Urbinati, A., Chiaroni, D., \& Chiesa, V. (2017). Towards a new taxonomy of circular economy business models. Journal of Cleaner Production, 168, 487-498.

[7] Murray, A., Skene, K., \& Haynes, K. (2017). The circular economy: an interdisciplinary exploration of the concept and application in a global context. Journal of business ethics, 140(3), 369-380.

[8] Kirchherr, J., Reike, D., \& Hekkert, M. (2017). Conceptualizing the circular economy: An analysis of 114 definitions. Resources, conservation and recycling, 127, 221-232.

[9] Goyal, S., Esposito, M., \& Kapoor, A. (2018). Circular economy business models in developing economies: lessons from India on reduce, recycle, and reuse paradigms. Thunderbird International Business Review, 60(5), 729-740.

[10] Jabbour, C. J. C., de Sousa Jabbour, A. B. L., Sarkis, J., \& Godinho Filho, M. (2019). Unlocking the circular economy through new business models based on large-scale data: an integrative framework and research agenda. Technological Forecasting and Social Change, 144, 546-552.

[11] Bloom, B. S. (1956). Taxonomy of educational objectives. Vol. 1: Cognitive domain. New York: McKay, 20-24.

[12] Prahalad, C. K., \& Hammond, A. (2002). Serving the world's poor, profitably. Harvard Business Review, 80(9), 48-59.

[13] Keerthan Raj, (2017). Indigenous Management Practices- A Case Study on 
Street Vendors. International Journal of Case Studies in Business, IT and Education (IJCSBE), 1(2), 29-36. DOI: http://dx.doi.org/10.5281/zenodo.914458.

[14] Keerthan Raj, \& Aithal, P. S. (2018). The Cockroach Theory for Sustainable and Scalable Organizational and Individual Growth. International Journal of Advanced Trends in Engineering and Technology, 3(1), 146149. DOI http://doi.org/10.5281/zenodo.1237899.

[15] Keerthan Raj, \& Aithal, P. S. (2018). A 'Desi' Multinational - A Case Study of Hindustan Unilever Limited. International Journal of Case Studies in Business, IT and Education (IJCSBE), 2(1), 1-12. DOI: http://dx.doi.org/10.5281/zenodo.1147365.

[16] Keerthan Raj, and Aithal, P. S., (2018). Literature Review of Impact of Branding on Base of the Pyramid Markets with Special Reference to India (March 6, 2018). International Journal of Applied Engineering and Management Letters (IJAEML), 2(1), 43- 63. DOI: http://dx.doi.org/10.5281/zenodo.1189047.

[17] Keerthan Raj, \& Aithal, P. S. (2018). Generating Wealth at the Base of the Pyramid - a Study Using ABCD Analysis Technique. International Journal of Computational Research and Development (IJCRD), 3(1), 68-76. DOI http://doi.org/10.5281/zenodo.1205586.

$* * * * *$ 